膝内障における膝関節周囲筋力評価

—Cybex II を用いて——

熊本大学整形外科
中 川 弘 彰・津 留 隆 行
水 田 博 志・坂 本 憲 史
甲 斐 功 一・益 田 郁 子
北 川 敏 夫

\title{
Evaluation of the Muscle Strength around the Knee in the Patients with Internal Derangement of the Knee by Using Cybex II Machine
}

\author{
by
}

\section{Hiroaki Nakagawa, Takayuki Tsuru, Hiroshi Mizuta, Kenshi Sakamoto, Koichi Kai, Ikuko Masuda and Toshio Kitagawa}

Department of Orthopaedic Surgery, Kumamoto University Medical School, Kumamoto.

It is well known that the knee muscle strength decreases in the patients with internal derangement of the knee. But it is difficult to evaluate the muscle strength adequately. In this paper, we quantified the quadriceps and hamstrings strength of 27 patients by using Cybex II machine. We discussed the usefulness of the Cybex II macine to evaluate muscle strength in the patients with internal derangement of the knee.

\section{は じめに}

膝内障に打ける膝関節周囲筋力は，診断上，病態解 析上，さらに治療上もきわめて重要な因子である。日 常の診察においては，筋力を測定するのに徒手筋力検 查が用いられる。また，筋萎縮の指標として大腿周径 差が用いられ，これをもって筋力の指標とすることが 多い。しかし，筋力と筋萎縮の相関関係については, いまだに十分検討されていない。 今回われわれは，膝 内障患者における膝関節周囲筋力の定量化を目的とし て Cybex II を用いた筋力評価を行ったので報告する。

\section{対象および方法}

症例は表 1 に示すように 27 名, 男性 20 名, 女性 7 名で, 年令は $8 \sim 49$ 才, 平均 24.3 才である. 疾患別内 訳は, 半月損傷 10 名, 前十字靯带損傷 1 名, 前十字靱
帯損傷に半月損傷を合併したもの 5 名, 後十字鞄帯損 傷 2 名, 内側側副靶带損傷 3 名, 膝内障 6 名である. 受傷時何らかのスポーツクラブに所属し, 毎日スポー ツ活動を行ったものをスポーツ群とし，それ以外を非 スポーツ群として分類すると, スポーツ群 17 名, 非ス ポーツ群 10 名である.Cybex II 膝関節周囲筋力測定の protocol にしたがい, 角速度 $5 \mathrm{rpm}\left(30^{\circ} / \mathrm{sec}\right)$ にて患 側と健側の膝屈曲力, 伸展力を測定した，得られた卜 ルク曲線からそれぞれのピークトルク值を測定し, 伸 筋の筋力を大腿四頭筋筋力, 屈筋の筋力をハムストリ ングスの筋力として評価した ${ }^{5)}$.また，健側に対する患 側の比を患/健比としてパーセント表示した（図1）。

\section{結果}

術前，大腿四頭筋のピークトルク值患/健比は平均 $77.1 \%$, 八ムストリングスは $88.1 \%$ であり, ハムスト 
表 1 対 象 患 者

\begin{tabular}{|c|c|c|c|c|c|c|c|c|c|c|c|}
\hline No. & 名前 & 年令 & 性 & 断 & スポーツ & No. & 名前 & 年令 & 性 & 診 & スポーツ \\
\hline 1 & F. K. & 47 & 女 & 左外側半月損傷 & & 15 & K. K. & 20 & 男 & 右後十字鞀帯損傷 & 陸上 \\
\hline 2 & H. T. & 17 & 女 & 右前十字䩲帯, 内側半月損傷 & & 16 & K. N. & 36 & 女 & 左内側半月損傷 & \\
\hline 3 & N. H. & 25 & 男 & 左内側側副靱帯損傷 & ラグビー & 17 & M. N. & 14 & 女 & 左外側半月損傷 & バスケット \\
\hline 4 & H. N. & 49 & 男 & 右膝内障 & & 18 & K. T. & 21 & 女 & 右膝内障 & \\
\hline 5 & H. U. & 23 & 男 & 左外側円板状半月損傷 & バレーボール & 19 & S. T. & 26 & 男 & 左前十字靶帯, 内側半月損傷 & サッカー \\
\hline 6 & H. U. & 25 & 男 & 右外側円板状半月損傷 & バレーボール & 20 & S.M. & 27 & 男 & 右前十字靶帯, 内側半月損傷 & \\
\hline 7 & J.H. & 8 & 男 & 左外側円板状半月損傷 & & 21 & H. N. & 20 & 男 & 左内側側副靭帯損傷 & ラグビー \\
\hline 8 & S. F. & 36 & 男 & 右内側半月損傷 & ジョギング & 22 & T. Y. & 21 & 男 & 左内側側副靭帯損傷 & ラグビー \\
\hline 9 & M. N. & 21 & 男 & 右後十字鞋帯損傷 & ラグビー & 23 & A. S. & 23 & 男 & 左前十字䨣帯損傷 & バレーボール \\
\hline 10 & H. S. & 21 & 男 & 右外側半月損傷 & & 24 & Y.H. & 14 & 男 & 右膝内障 & バレーボール \\
\hline 11 & N. I. & 18 & 女 & 左前十字靱帯, 内外側半月損傷 & バレーボール & 25 & K. I. & 24 & 男 & 右内側半月損傷 & バレーボール \\
\hline 12 & M. A. & 25 & 女 & 左膝内障 & & 26 & T.M. & 9 & 男 & 左外側円板状半月損傷 & \\
\hline 13 & M. K. & 22 & 男 & 右膝内障 & 空手 & 27 & N. K. & 48 & 男 & 右膝内障 & ジョギング \\
\hline 13 & K. H. & 16 & 男 & 右前十字靭帯, 内側半月損傷 & ラグビー & & & & & & \\
\hline
\end{tabular}

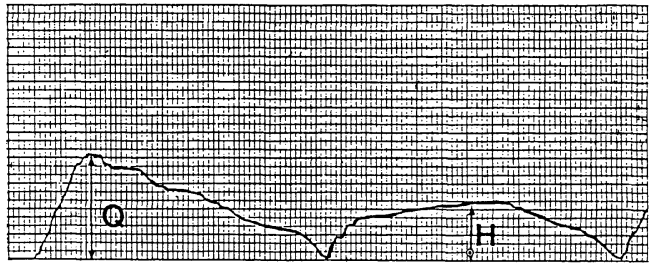

大腿四頭筋ピークトルク值 $=0$

ハムストリングスピークトルク值 $=\mathrm{H}$

患 $/$ 健比 $=\frac{\text { 患側 } \mathrm{Q}}{\text { 健側 } \mathrm{O}}$ おょび $\frac{\text { 患側 } \mathrm{H}}{\text { 健側 } \mathrm{H}}$

図 1 Cybex IIによって得られたトルク曲線と患/健比

リングスより大腿四頭筋の筋力低下が著しい.

スポーツ群, 非スポーツ群にわけて, 大腿四頭筋ピ ークトルク值を比較してみると, スポーツ群では非ス ポーツ群にくらべて患側健側とも2 倍以上の高值を示 した（図 2 ). 。た，患/健比を比較してみると，大腿 四頭筋ではスポーツ群 $(78.7 \%)$ と非スポーツ群 $(74.4$ \%）の間に有意差はなかったが，ハムストリングスで は, スポーツ群で $97.1 \%$ と患側の筋力低下はほとんど なく, 非スポーツ群 $(72.7 \%)$ と有意な差を示した $(\mathrm{p}<$ $0.05)$.

次に Cybex IIトルク值と徒手筋力検査での評価を比

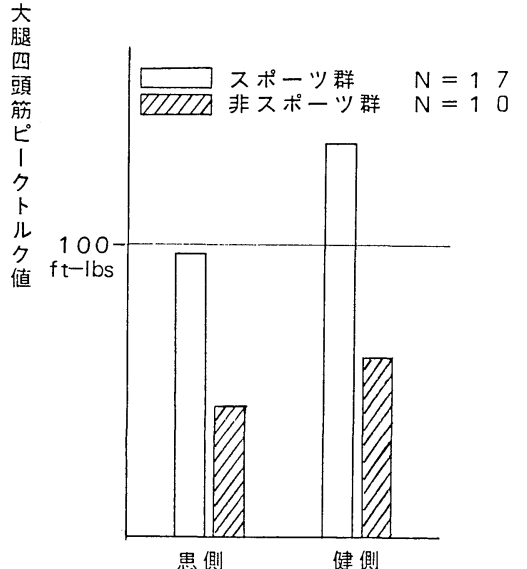

図 2 スポーツ群，非スポーツ群における大腿四頭筋 筋力の比較

較すると, 患側の筋力は, 徒手筋力検查では 5 と 4 の 2 段階のみで評価されておりその Cybex IIトルク值は, 非常に広いバラツキを示した(図 3 )。次に，大腿周径 差 (膝蓋骨上緑より $10 \mathrm{~cm}$ 近位) とピークトルク值患/ 健比の関係を示す (図 4 ). 大腿周径差が大きくなるに つれて, 患/健比も小さくなるすなわち患側の筋力も低 下する傾向が見られるが，明らかな負の相関は大腿四 頭筋，ハムストリングス共に見られなかった。 
筋力 5 につて

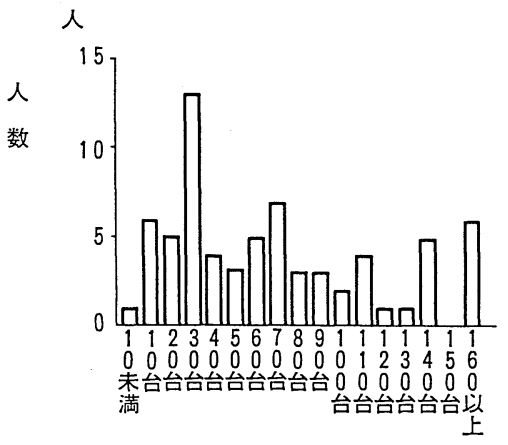

筋力 4 について

人

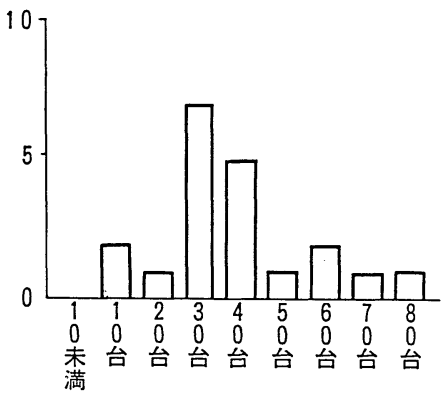

CYBEXII トルク值

図 3 徒手筋力検査と Cybex IIトルク值との比較

ハムストリングス
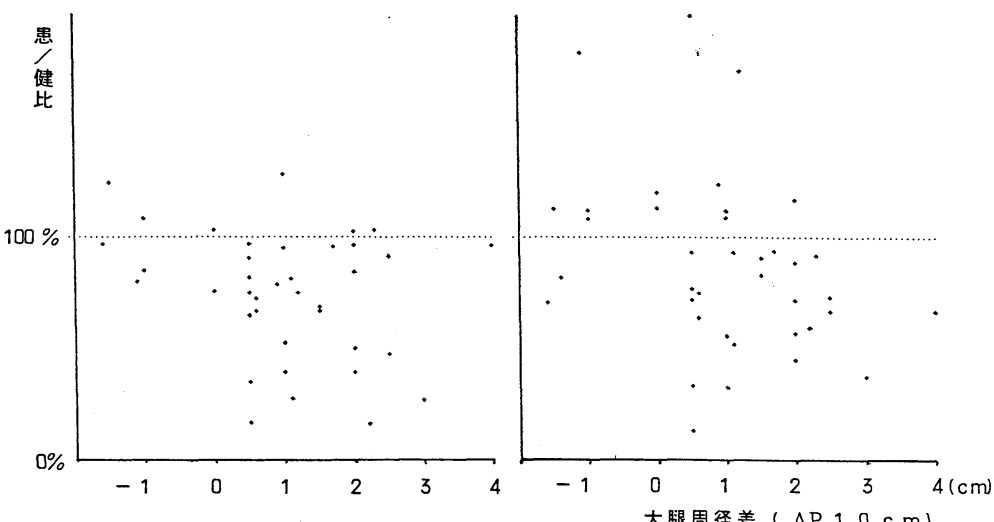

図 4 大腿周径差とピークトルク值患/健比の関係

術前術後に多数回 Cybex IIによる測定を行った 7 症 例に対し, その術前トルク值を 100 とし, 術後のトル ク值の推移を図 5 に示す。患側大腿四頭筋筋力の術後 の回復さらには，筋力増強が容易でないことがうかが える。また，術後の訓練が患側のみになされているに もかかわらず，健側の四頭筋の筋力上昇が多数認めら れた。

\section{考察}

半月損傷，靱帯損傷などの膝関節外傷においては, 膝関節周囲筋，とくに大腿四頭筋の筋力低下がおこる ことは良く知られている。また，膝内障患者における
筋力はその患者の症状発現とも関係し ${ }^{1)}$,さらに $\mathrm{McDaniel}^{3)}$, Hamberg ${ }^{2)}$ などの報告にもあるように， 手術後の予後を左右する重要な因子である．従来の徒 手筋力検査によると, 膝内障の膝関節周囲筋力はほと んど 5 と 4 の 2 段階のみで評価されるが, Cybex II よるピークトルク值でみると非常に広いバラツキが見 られ，筋力の評価としては妥当とは言えない.

また, 大腿周径差とピークトルク值患/健比との間に も，はっきりとした相関は認められず，さらに大腿四 頭筋と八ムストリングスでは筋力低下の程度がちがう こともあわせると，大腿周径差をもつて膝関節周囲筋 力の代用とすることは必ずしも妥当ではないと考える. 
患側大腿四頭筋

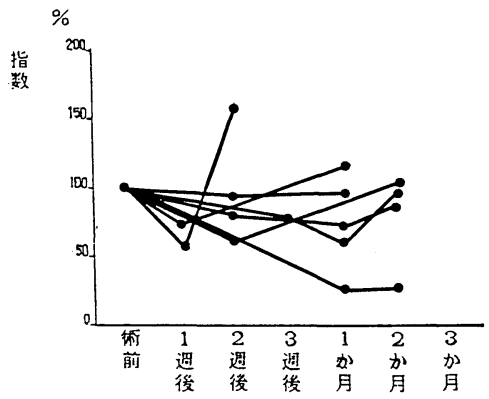

健側大腿四頭筋

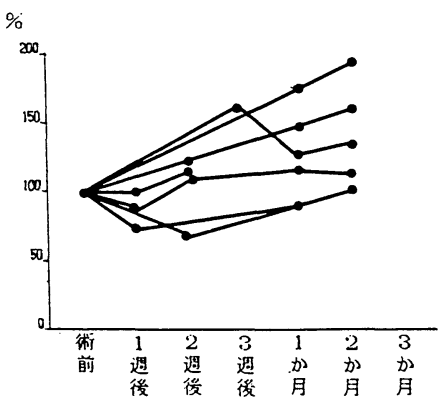

患側ハムストリングス

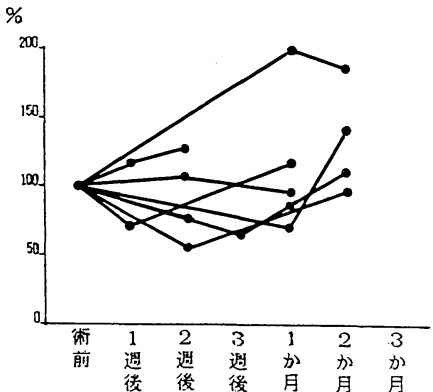

健側ハムストリングス

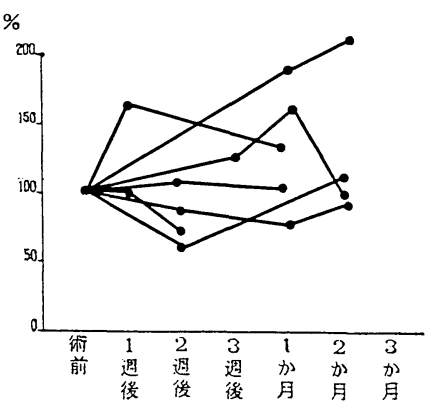

図 5 Cybex IIによる手術例の筋力の推移

さらに今回われわれの測定では，スポーツ群では非ス ポーツ群にくらべて, 大腿四頭筋, ハムストリングス 共にピークトルク值が高く, また，患側ハムストリン グスでは筋力低下がほとんどないなどの特殊性が見ら れた。また, 今回は症例数が少く, 疾患別の検討はで きなかったが，疾患による特殊性も当然考えられうる ところである。このように，膝内障においては，膝関 節周囲筋力の症例毎の詳細な検討，とくに定量化は病 態解析あるいは治療の上でも非常に重要であり，その 点Cybex IIによる測定は有用であると考える.

Cybex IIの利点は, (1)あらゆる角度での筋力を定量 的に評価できる(2)瞬発力 (FT 線維)のみならず持久力 $(\mathrm{ST} \text { 線維 })^{4)}$ の評価ができる(3)測定機器としてのみな らず，訓練機器として応用できるなどがあげられる。

われわれは, 今後 Cybex II を用い, 膝内障と膝関節 周囲筋力の関係の詳細について, 検討を重ねて行く予 定である.

$$
\text { ま と め }
$$

われわれは膝内障 27 症例に対して Cybex II による膝
関節周囲筋の筋力評価を行い，結果を報告するととも に，その有用性について述べた。

文献

1) Giove, T.P. et al. : Non-operative treatment of the torn anterior cruciate ligament. J. Bone and Joint Surg. 65-A : 184-192, 1983.

2) Hamberg, P. et al. : The effect of diagnostic and operative arthroscopy and open meniscectomy on muscle strength in the thigh. Am. J. Sports Med. 11 : 289-292, 1983.

3) Mcdaniel, W. J. et al. : Untreated ruptures of the anterior cruciate ligament. A follow up study. J. Bone and Joint Surg. 62-A : 696-705, 1980.

4）清水直史 - 他：膝前十字靱帯再建術後の大腿四頭筋 萎縮について。臨床スポーツ医学, 3:529-535, 1986.

5）大井淑雄 - 他：等運動性筋収縮の理論と整形外科領 域への応用について. 日整会誌, $50 ： 1011-1021,1976$.

質 問州労災病院 井原 秀俊

(1) $\mathrm{ADL} ・$ スポーツ時に膝周囲が働くのは足が地面 についた立位状態がほとんどであることから考えると 
坐位での Cybex による評価は, 果たして正しい筋の評 価といえるのだろうか？

(2) 正常歩行の際も, $270^{\circ} / \mathrm{sec}$ という速い角速度が働 くという報告も存在する. 5 RPM という遅い角速度で の評価が妥当であるか?

(3) 筋訓練とともに反応スピードにも変化があらわ れることが予想されるが，ピークトルク值に達する膝 屈曲角度に変化がみられたか?

解 答 熊本大学 中川 弘彰

(1) Cybex II は，坐位で簡単に膝の屈曲力・伸展力
を定量化することができる. 今回は，その Cybex II の 利点を生かして膝周囲筋力を測定し報告した。立位で の膝周囲筋力については今後検討していきたい.

（2) 過去の報告でも 5 RPM でおこなった報告が多 く，結果を比較できるためにこの角速度を選んだ。

（3) 患側と健側とを比較した場合，患側のトルク值 がピークに達するまでの時間は健側にくらべて延長し ていた．この時間は，訓練によって短縮すると予想さ れるが、今回われわれの測定でははっきりとした結果 は得られなかった。 